\title{
MAPPING OF EXISTING MARICULTURE ACTIVITIES IN SOUTH-EAST SULAWESI "POTENTIAL, CURRENT AND FUTURE STATUS”
}

\author{
Hatim Albasri" ${ }^{* \#}$, Wa Iba*), La Ode M. Aslan ${ }^{* *}$, Geoff Gooley ${ }^{* * *}$ and Sena De Silva ${ }^{* * * *}$ \\ *Indonesian Center for Fisheries Aquaculture Research and Development \\ *) Faculty of Fisheries \& Marine Science, Haluoleo University, Indonesia \\ ${ }^{* *}$ Fisheries Victoria Department of Primary Industries, Australian Government \\ ${ }^{* * * *)}$ Network of Aquaculture Centres in Asia-Pacific, NACA
}

(Received 29 October 2010; Accepted 2 December 2010)

\begin{abstract}
The present study identifies existing mariculture activities and its constraints in SE Sulawesi, along with its geo-physical attributes in the Province.This allows for a better understanding the potential, current and future status of mariculture development in the area and making sure its sustainability. The study was conducted to map the existing mariculture activities in SE Sulawesi. Data collection was performed in June 2009. Spatial and attribute data of the existing mariculture were acquired by interviewing fish farmer using open-ended questionnaire and analyzed using ArcGIS 9.x. Key water quality parameters consisted of temperature, dissolved oxygen, $\mathrm{pH}$, salinity, depth, clarity, and turbidity and analyzed using STORET Indeks. Three big clusters of existing mariculture activities are located in Kendari, Muna and Buton areas, collectively serving as both a source of mariculture products and a market destination or transit location. All surveyed locations of existing mariculture activities in SE Sulawesi show relatively optimal water quality conditions. Site capacity and suitability analysis of existing or potential areas of mariculture activities and development have largely not been considered by stakeholders involved in managing coastal areas, resulting in crowded and unmanaged development with multiple overlapping economic activities in some areas. Piloting of integrated 'value-adding' mariculture industries (e.g. raw material, processed products and 'ready to eat' industries) might help ease some if not all of the existing economic problems of the mariculture sector.
\end{abstract}

KEYWORDS: existing mariculture, water quality, GIS, Southeast Sulawesi

\section{INTRODUCTION}

In recent times, fisheries-based economic activities in Southeast Sulawesi have gradually been replaced by aquaculture due to degradation of natural coastal and marine fisheries resources. One example is the significant fish stock depletion in Wakatobi Regency, which has forced local government to initiate a fisheries management program to monitor and control fishing practices in the area (May \& Coles, 2004). SE Sulawesi Province is currently supporting mariculture as one of its long term development goals, as evidenced by programs such as pilot projects on abalone and grouper mariculture, and capacity building for seaweed farmers (DKP Sultra, 2005).

\# Corresponding author. Indonesian Center for Fisheries Aquaculture Research and Development, Jl. Ragunan 20, Pasar Minggu, South Jakarta 12540, Indonesia. Tel.: + 62217805052

E-mail address: hatim@cria.indosat.net.id 
Among many cultured species in SE Sulawesi, grouper, sea cucumber, lobster, sea weed, pearl oyster and abalone are most favored by producers, with abalone in particular gaining popularity in the past ten years due to high market demand and price. Other species have also been cultured such as shrimp, crabs and other fish species. Most fish farmers in SE Sulawesi use either traditional or semi-intensive mariculture techniques with limited inputs to increase final yield. A small number of wellestablished and well-funded producers have applied intensive mariculture systems to boost production and/or to culture high-value mariculture products such as grouper and pearl oyster (Albasri \& Szuster, 2010).

The objective of the present study was to map the existing status and geo-physical attributes of mariculture activities in the Province, including seed source, production and distribution of key species, practiced mariculture techniques, key water quality and other bio-physical parameters to characterize the existing mariculture activities in SE Sulawesi. It is expected that this study will provide valuable information to key mariculture sector stakeholders, including business entities and individuals, government agencies, researchers and to the fish farmers themselves in order to develop sustainable yet profitable mariculture in SE Sulawesi.

\section{MATERIALS AND METHOD}

\section{Study Area}

The present study was conducted within the region of South-East Sulawesi Province, and focused on the mapping of existing mariculture activities and related aspects in three regencies (Muna, South Konawe and Buton) and two municipalities (Kota Kendari and Kota Baubau) (Fig. 1).

The study location was chosen based on the identification of mariculture farmer groups (Dinas et al., 2009), where 47 villages were selected based on their significant contribution and potential to the mariculture development in the corresponding regencies.

\section{Data Collection}

Data collection commenced on June 22 , 2009 and lasted for 20 days. Spatial and attribute data of existing mariculture activities

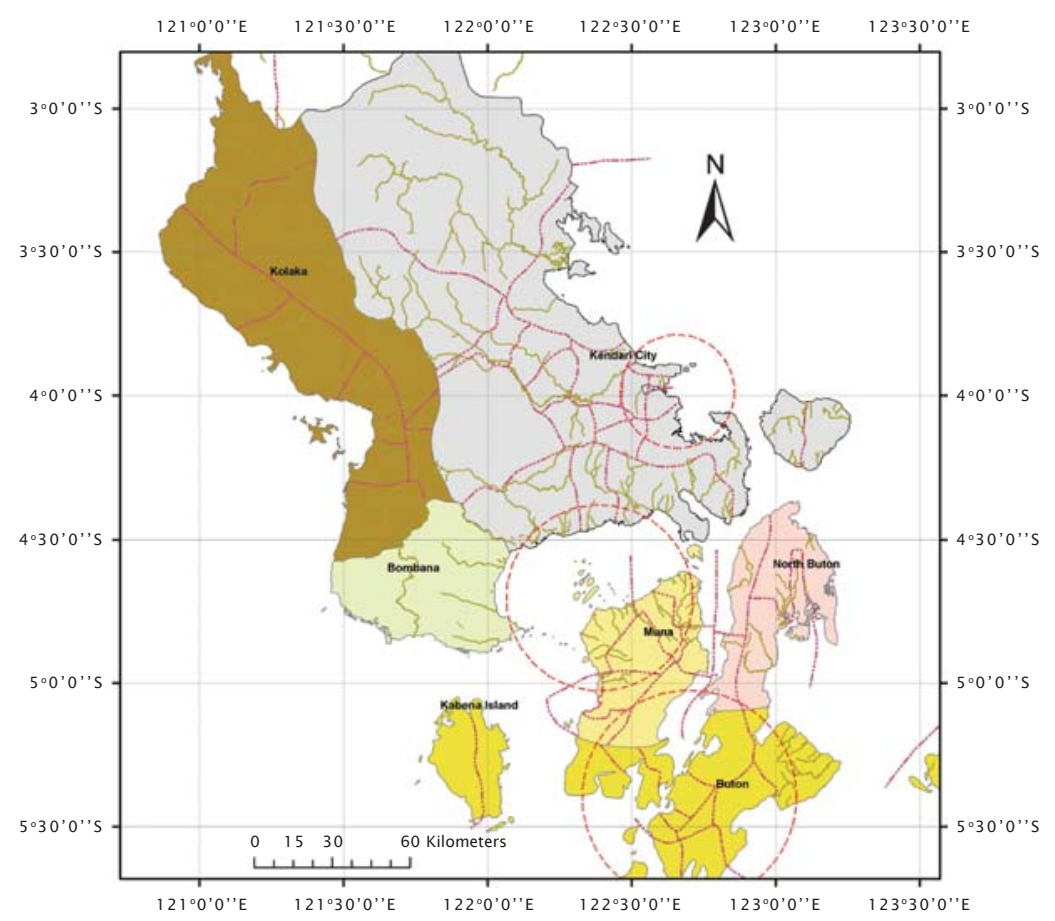

Figure 1. Map of study area (South-East Sulawesi) 
and key water quality parameters were the two main categories of the required data in this study.

\section{Study Preparation}

In order to minimize subjectivity and maintain data consistency, a set of open ended questions were prepared in the form of a questionnaire to be asked to potential interviewees. The questions were about the mariculture activities conducted by the interviewees, including farmer's details, technical aspects of practiced activities, post harvesting techniques and market availability. The other preparation that was made for this study was acquiring digital maps of the study area from Bakosurtanal (Coordinating Agency for National Mapping and Survey). These maps were 1999 Indonesian Digital Map and 1991 Topographical Map of Southeast Sulawesi Regencies. Some key spatial factors such as street, city location, harbor, administrative boundary and topographical contours were drawn from these maps, which then were refined using data from previous unrelated research. Base maps were also prepared from these maps in guiding the field survey and assisting interviewees.

\section{Spatial and Attribute Data Collection}

Spatial and attribute data collection was performed to depict the distribution of existing mariculture activities and its related aspects. Location of mariculture activities were plotted using a handheld GARMIN GPS to record village location, and a GARMIN GPS MAP 298/ 278 was used to record location of fish farms and sampling stations of water quality parameters. Attribute data of the existing mariculture activities were acquired by interviewing fish farmers on location using the previously mentioned questionnaire. Interviewees were randomly selected from each location/village. One type of mariculture (i.e. grouper or abalone mariculture) was represented by one interviewee/fish farmer.

\section{Water Quality Measurement}

Key water quality parameters measured in this study consisted of temperature, dissolved oxygen (DO), pH, salinity, depth, clarity (Secchi depth) and turbidity. All of these parameters were measured in situ. At every location, water quality parameters were measured using simple random sampling to determine the location of sampling stations (Clark \& Hosking, 1986). Water quality parameters were consistently measured during daylight hours from 09.00 AM to 03.00 PM to limit bias. Water quality data were then analyzed using IKA_STORET method (Centre, 1977) to depict the suitability of the location with the existing mariculture activities, and compared to the standard water quality parameter of the corresponding cultured species. According to Centre (1977) water quality condition is determined as 'good' if the total score of Storet value is between - 1 and -10 .

\section{Data Analysis}

Spatial and attribute data were analyzed using ArcGIS 9.1. Locations of existing mariculture were plotted on digital basemaps to depict their distribution across the landscape of SE Sulawesi.

\section{RESULTS AND DISCUSSION}

Distribution of Existing Mariculture Activities in South-East Sulawesi

There were eight villages taken as samples of this research representing the existing mariculture activities in Muna region, seven in Kendari region and 22 villages in Buton region. A list of villages and their attribute information is presented in Tables 1, 2, and 3. The location of key mariculture activities in the three designated study areas within SE Sulawesi are graphically depicted in Figures 2, 3, and 4 for Kendari, Muna and Buton respectively. In general, almost all existing mariculture activities in SE Sulawesi practice similar techniques for the same species, and likewise face similar problems in business development.

\section{Seaweed}

Eucheuma (Kappaphycus) cottonii is the only seaweed species cultured in SE Sulawesi at the moment, although wild stock of other species such as Gracilaria verrucosa can be found around Muna Island and Buton. Rope or "tali" on which seaweed is cultured is the common term for the production unit used as a measure of the scale of any one seaweed farm. On average, each producer in SE Sulawesi has $30-45$ ropes. If one rope has an average length of $100 \mathrm{~m}$, then each farmer typically has more than $3 \mathrm{~km}$ of $100 \mathrm{~m}$ ropes placed parallel to each other and stretched from the beach to 


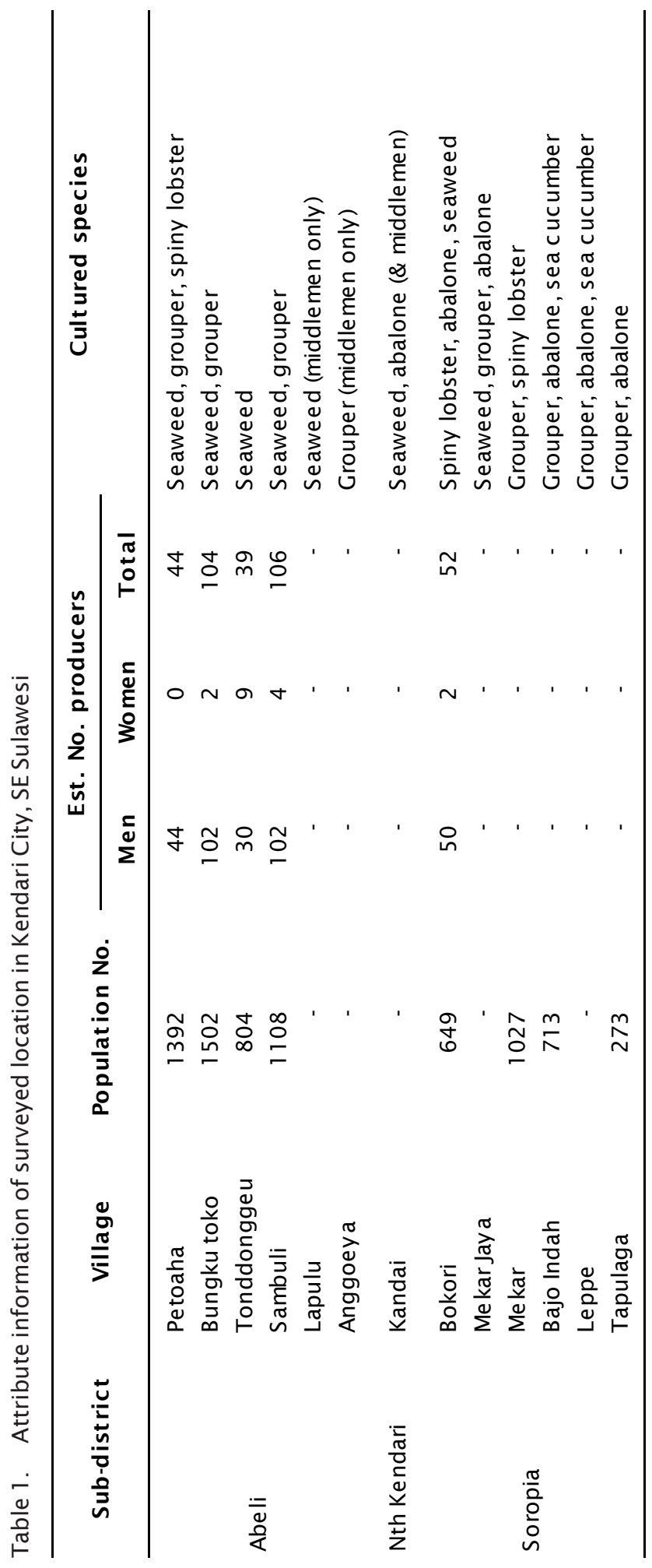




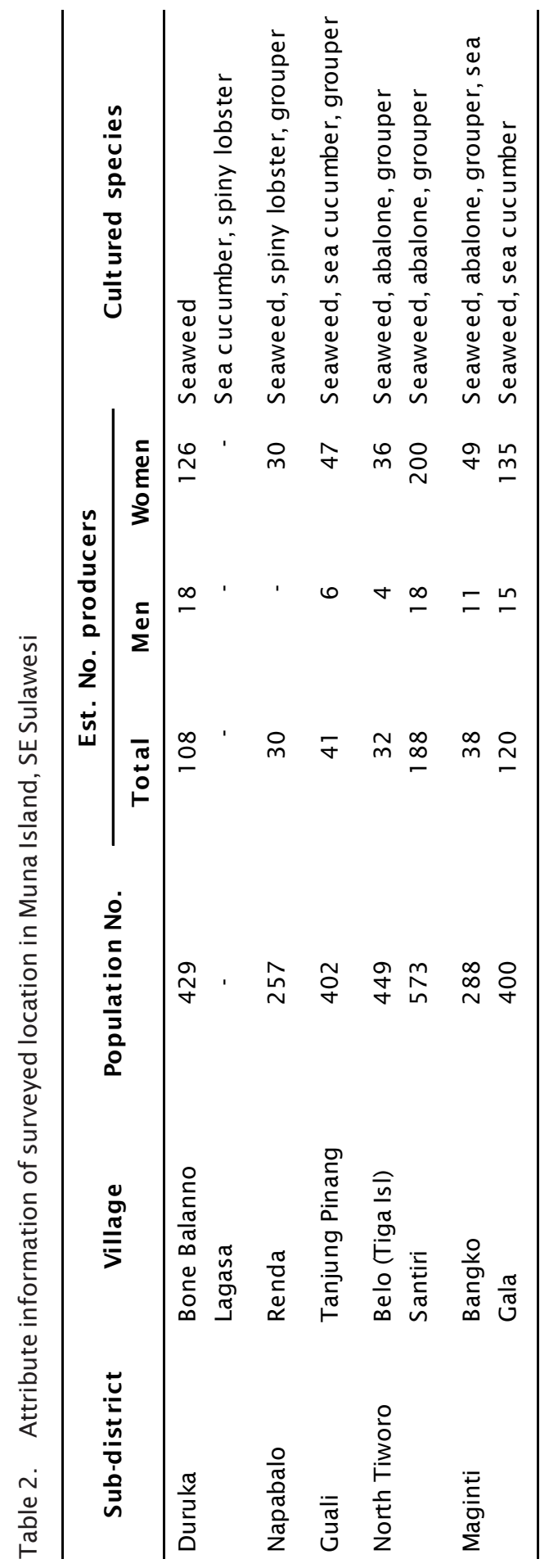




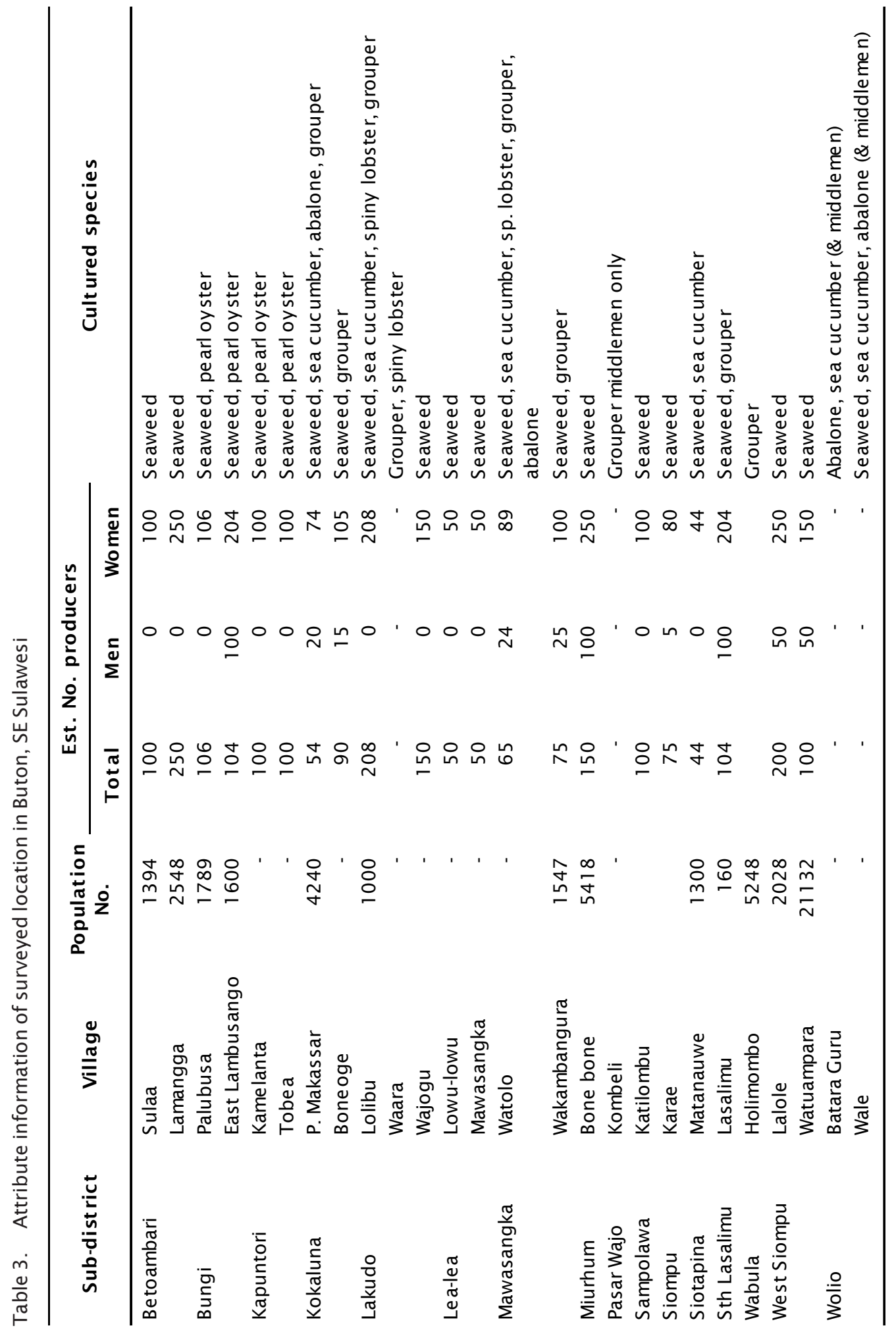



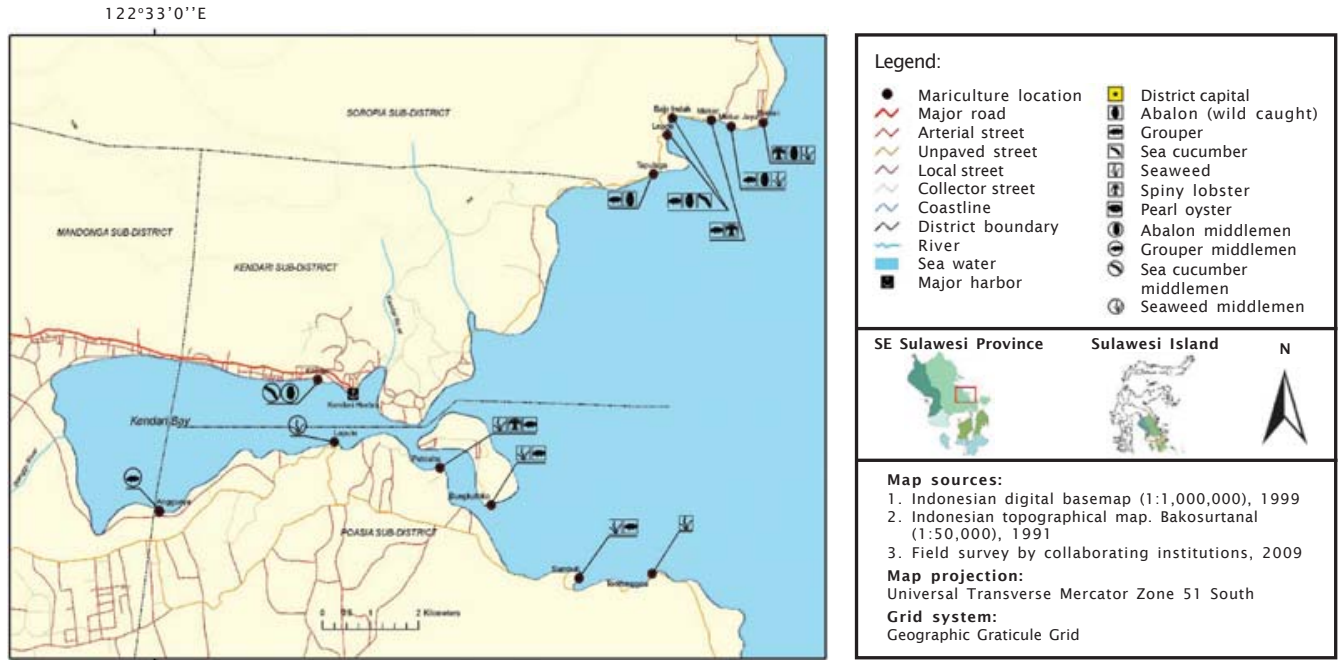

$122^{\circ} 33^{\prime} 0^{\prime \prime} \mathrm{E}$

Figure 2. Location of existing mariculture activities in Kendari Region
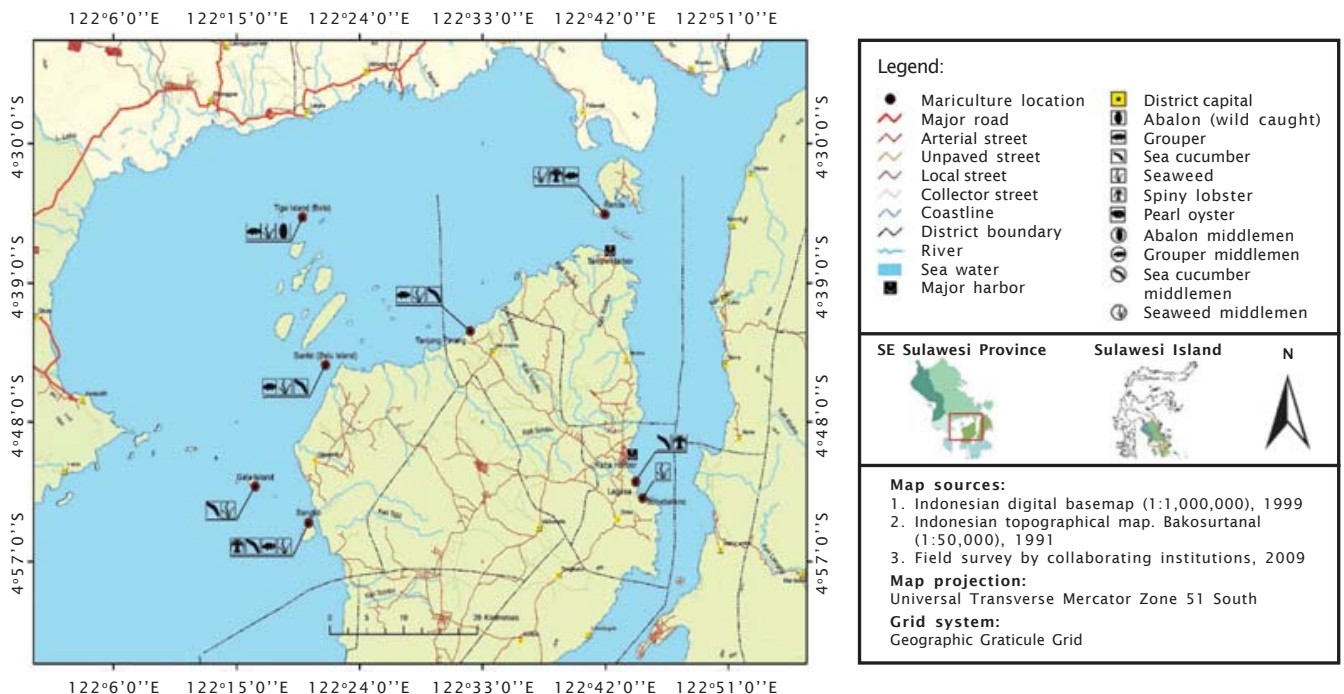

Figure 3. Location existing mariculture activities in Muna Regency

the sea. This practice has been the source of several problems and conflicts with other coastal users.

The most common practice to cultivate seaweed in Muna Island and Kendari is using long-line with seed plants tied along the ropes with 15-20 cm gap. In Buton however, longline and raft systems have both been used. Seed is collected from farmers who specialize in culturing seeds of seaweed or from farmers with seaweed that has been cultured for not more than 20 days. Seaweed is favoured by farmers due to the limited effort required.

Besides problems from epiphytic algae and natural predators such as the herbivorous rabbit fish, Siganus siganus, "ice-ice" disease is the most common problem faced by seaweed farmers. Some seaweed farmers deal with this problem by not cultivating seaweed if news of "ice-ice" outbreak is heard, or not cultivating 

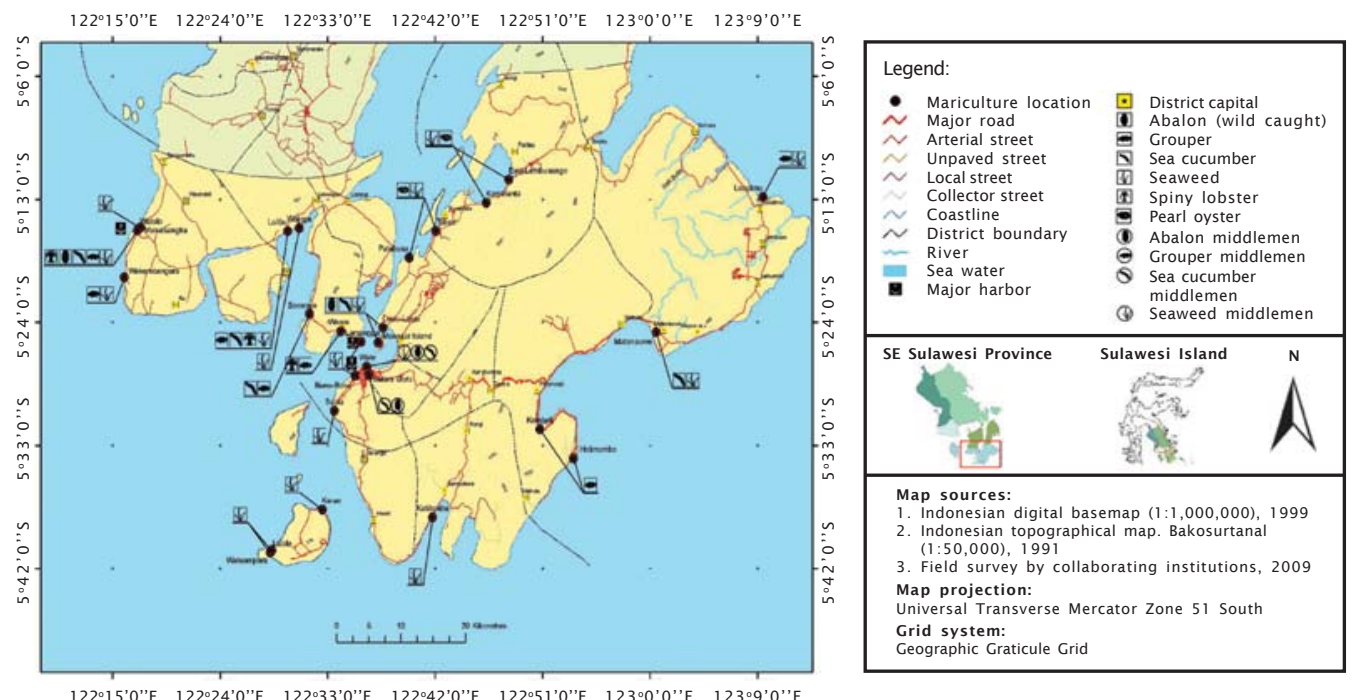

Figure 4. Location of existing mariculture activities in Buton Region

in the periods when "ice-ice" is known to most likely occur. Another problem with the development of this sector in SE Sulawesi is that seaweed is sold as raw product with no processing or other value-adding. There has been little effort in Indonesia in general to develop integrated seaweed industry that combines mass production with supporting post-harvest industries. Final price of seaweed can be increased significantly by processing to extract thickeners/carageenans used as raw materials for cosmetics, food and medicinal products. By developing such integrated industries in SE Sulawesi, seaweed production would be boosted, supply chains streamlined and margins and overall livelihood and well being increased for all stakeholders.

\section{Grouper}

From 47 villages surveyed in this study, five villages in Muna, eight villages in Kendari and seven villages in Buton were identified to have existing grouper mariculture. The most sophisticated methods of culturing grouper occur in the Kendari area where floating net cages are well constructed and equipped with electricity, backup generator and in some cases living quarters for staff (even including air-conditioning in one facility off Bokori village). Fixed net cages are also still widely used to culture grouper in Kendari by traditional fish farmers. In Muna and Buton, most farmers use fixed net cages attached to the back of their houses for reasons of security and practicality in monitoring the fish. Additionally, some farmers in Buton are using ponds to culture grouper, especially for tiger grouper. The high risk involved, lack of financial resources, technical expertise and institutional support are the main constraints preventing farmers moving to better management practices for grouper culture in SE Sulawesi.

Of the 15 genera and 159 species of groupers available in Indonesia, the most favored genera to be cultured in SE Sulawesi and Indonesia in general are Epinephelus and Mycteropera (Pierre et al., 2007). E. tauvina, Cromileptes altivelis and E. coioides are the most common species used in fixed and floating net cage culture in Muna, Kendari and Buton.

There are two main sources of grouper seedstock in SE Sulawesi. In Muna and Buton, wild-caught seed is collected from surrounding coastal waters by the fish farmers themselves or by local fishermen who then on-sell to the farmers. In Kendari, wild-caught seed is collected and purchased from local fishermen, and hatchery-bred seed is purchased from Bali. One particular fish farmer in Lolibu village, Buton, has tried hatchery-bred seed from Bali but with disappointing results, as most fish died before they reached marketable size. Poor seed quality, unsuitable environment and in- 
correct handling techniques were blamed by the farmer, who subsequently relies only on wild-caught seed.

Most grouper farmers using fixed net cage systems in surveyed locations practice traditional rearing and feeding techniques. In Muna and Buton, grouper are fed once or twice daily, depending on the availability and supply of fresh trash fish supplied by local fishermen. In Kendari, farmers have begun to use pelleted feed to reduce the dependence on trash fish. Improved feeding techniques with measured feeding rates of $5 \%-10 \%$ of total body weight/ day apply for semi-intensive and intensive floating net cage systems. Little is known about the post harvesting processes for grouper culture due to the fish being transported live outside the country to be sold, processed and served in restaurants in Hong Kong, China, Singapore, and Taiwan.

\section{Sea Cucumber}

Out of 47 surveyed villages, only one village in Kendari and five villages in Buton and Muna combined were identified as supporting sea cucumber culture activity, of which only Lolibu Village, Buton Regency, was still culturing sea cucumber at the time of the field survey. Other locations were identified as having sea cucumber culture activity based on information from interviewees and previous surveys as part of the ACIAR project.

In Lolibu Village, only one farmer cultures sea cucumber, the sandfish (Holothuria scabra). Wild-caught seed is collected from nearby shores by the fish farmer himself, or by local fishers. The seeds are placed in traditional stone ponds sized $125 \times 50 \mathrm{~m}$ at a stocking density of about 2,000 seed/pond. They are fed once a week with crumbled sea urchin and left over/trash fish. They reach market size after about seven months, with a harvest of $100-200 \mathrm{~kg}$ of fresh sea cucumber. Once harvested, they are cleaned and dried and sold at market size to a buyer from Jakarta.

The major problem faced by the farmer in Lolibu village, as for other sea cucumber farmers in the Province, is that it is difficult to contain sea cucumber in traditional ponds (Fig. 9). The farmer has expressed his concern by stating that "..... culturing sea cucumber is like rearing genies. One day you stock 2,000 seeds, and the next day every one of them is gone, no matter how well you secure your pond".

\section{Abalone}

Abalone mariculture in SE Sulawesi has recently been initiated by several agencies and institutions with collective responsibility for developing mariculture and associated production systems in this Province. The commercialization of abalone culture in the Province is still fully dependent on supply of wild caught stock. Among 47 surveyed villages, three villages in Muna (Belo, Santiri, Bangko), five villages in Kendari (Bokori, Mekar Jaya, Bajo Indah, Leppe and Tapulaga) and only two in Buton (Watolo and Pulau Makassar) have marketed abalone from culture-based activities.

The development and adoption of abalone culture by traditional fishers in SE Sulawesi faces several major problems, including decreasing stock of wild-caught seed, a lack of hatchery-bred seed for regular supply to farmers, low level of expertise in abalone farming techniques, and a lack of support from local government in the form of training, capacity building and market information.

\section{Pearl Oysters}

Buton is the only region where pearl oyster (Pteria penguin) mariculture is undertaken in SE Sulawesi. Four villages are currently culturing pearl oysters i.e. Palubusa, East Lambusango, Kamelanta and Tobea, although production is presently in decline. Decreasing water quality at the production sites, and expansion of seaweed farming have collectively undermined prospects for pearl oyster farming in SE Sulawesi.

The average size of each floating net cage is around $16 \times 10 \mathrm{~m}$, consisting of 15 boxes in which cultured pearl oysters are placed, each of which is stocked with 7.000-10.000 individual, wild-caught seed oysters purchased from fishermen at Kapuntori bay. The boxes are placed in steel frames and lowered to a depth of 15-25 $\mathrm{m}$. The culturing period for pearl oyster is up to six months before it can be harvested and sold to the local private pearl oyster farm for purpose of pearl production.

With the recent expansion of seaweed farming in Buton regency, a major problem faced by pearl oyster farmers is gaining ready and safe access to net cage platforms. The platforms are increasingly surrounded by seaweed farming infrastructure, which is causing difficulty in undertaking routine maintenance and 
management. Recent developments in seaweed farming where liquid fertilizer is being used by farmers in the area to boost production is posing another risk for the industry. Decreasing water quality from pollution caused by boats and other small vessels passing the area has been also been claimed by one pearl oyster farmer in Palabusa village. There are no local government planning provisions in place to ensure that pearl oyster mariculture can maintain its existence side by side with seaweed farming. A designated management area based on site suitability analysis and spatial layout for mariculture activities is required in order to prevent impacts.

Most producers in SE Sulawesi are still practicing traditional mariculture techniques, using wild-caught seed of local species sourced and reared close to their homes. Locally available materials are used for constructing production facilities, including cages, pens and platforms, with low input and density rearing techniques producing relatively low output. The lack of financial support, knowledge and skills, market information and institutional assistance have made it difficult for these producers to enhance profitability and overall welfare of livelihoods through mariculture activities.

Mariculture site capability and suitability analysis of existing mariculture activities and potential area for development in SE Sulawesi has not been utilized by stakeholders involved in coastal zone management. The lack of properly planned, integrated management areas for multiple overlapping economic activities in the Province has resulted in crowded and poorly managed coastal development. Sensitive mariculture activities, such as pearl oyster production, have been forced from the area due to a lack of adequate planning and management, particularly as a result of environmental impacts form other activities.

Finally, the supply chain for many mariculture products in SE Sulawesi is relatively long, especially for seaweed, grouper and spiny lobster. Production locations with no land transportation (small islands), or which are geographically isolated from market centres, are at a particular disadvantage. as farmers incur greater costs to get their products sold. Shorter, more integrated supply chains would reduce costs, and increase quantity and quality of products and overall profitability of farmers. Developing integrated local industries which add value to raw materials through processing and production of 'ready to eat' products would be advantageous to the livelihood of local fish farmers in particular and for the economy of SE Sulawesi in general.

\section{Key Water Quality Parameters At Mariculture Locations In SE Sulawesi}

The general bathymetry of the coastal zone of SE Sulawesi, incorporating the major mariculture production centres for the species of interest to this study, is provided in Fig. 5. This highlights the extensive area of relatively shallow, protected coastal waters in which existing mariculture activities take place in the Province.

Considering the scale of this potential and the current status of Indonesian aquaculture, a precautionary approach to development is necessary to ensure the sustainability of aquaculture activities and associated impacts on natural resources. Indeed, mariculture activities should comply with national strategy in developing coastal and marine areas throughout Indonesia (Stead et al., 2002; GESAMP, 2001). Specifically, monitoring and assessment of key water quality parameters are critical factors determining the success and sustainability of any mariculture activities (Purnomo, 1992).

\section{Muna Island}

IFrom six measured parameters, only $\mathrm{pH}$ and water clarity are rated as 'fair', but both parameters are typically variable and subject to ambient weather and oceanic conditions. Under these conditions, one-off measurements are of limited value in assigning overall ratings.

\section{Temperature}

According to Gunarso (1985), most fishes are sensitive to temperature variation. Optimal temperature for fish culture in tropical climates is generally ranging between $27^{\circ} \mathrm{C}-32^{\circ} \mathrm{C}$ (Mayunar et al.,1995). Water temperature in the location of existing mariculture activities around Muna Island varies between $28.5^{\circ} \mathrm{C}-$ $30.6^{\circ} \mathrm{C}$. This value is categorized as suitable for mariculture according to the standard by the KLH (2008).

\section{Water Clarity}

In the present study, water clarity of waters around Muna Island is still in good condi- 


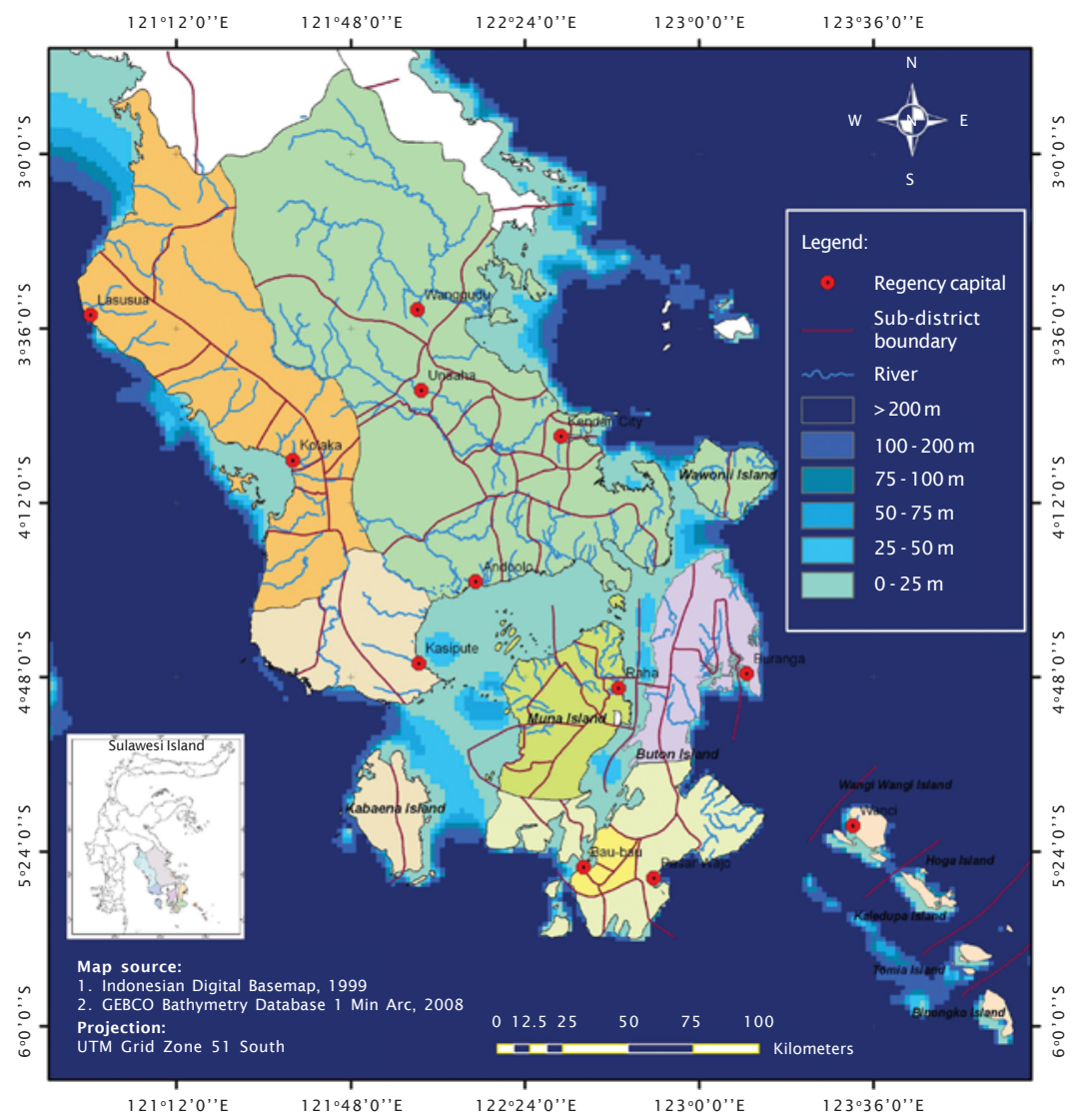

Figure 5. General bathymetry of key mariculture areas of SE Sulawesi

tion, with secchi disk depth ranging between 1.25-11 m. Based on the Storet analysis, water clarity scored -1 which means that sunlight penetration in the water is ranging from 'poor to optimal'. By looking at the total score of Storet index, the waters off Muna Island are classified into B class, which is an overall rating of 'good'.

\section{Water Depth}

Based on observation in the present study, most fish farmers in the Muna area place their net pens in water with a depth clearance of 1.25-41.5 m. For seaweed farmers, the depth for cultivation ranges between $0-30 \mathrm{~m}$.

\section{pH}

Boyd \& Licthkoppler (1982) suggest that the optimum range of $\mathrm{pH}$ in fish culture is between 6.5-9, with $\mathrm{pH}$ levels lower than 4 and above 11 being toxic to fish. Waters around Muna Island during the present study had a pH value between 6.4-8.3. Based on Storet analysis score of -2 , this area is rated as suitable for mariculture activities.

\section{Dissolved Oxygen}

Dissolved oxygen (DO) is considered one of the most important factors in fish culture. It is influenced by temperature, partial gas pressure (elevation/altitude) and salinity (Boyd \& Licthkoppler, 1982). According to Cholik et al. (1986) and Sunarti (1992), fish become inactive and growth is limited if DO concentration in culture media is lower than $3 \mathrm{mg} / \mathrm{L}$ for prolonged periods. Measured DO levels in waters off Muna Island during the present study varied between $4.2-7.9 \mathrm{mg} / \mathrm{L}$. With a Storet index value of -2, DO levels in waters around Muna Island are rated as moderate to highly suitable for mariculture. 


\section{Salinity}

Salinity variation occurs in coastal areas due to tidal changes, freshwater run-off from nearby land and evaporation. The range of salinity levels that is considered optimal for mariculture is different between species. Salinity levels in waters off Muna Island range between 32.1-33.6 mg/L (ppt), and are considered optimal for existing mariculture activities (KLH, 2004). Based on Storet analysis, salinity levels in waters off Muna Island scored 0 , with a rating of 'good' for mariculture activities in this region.

\section{Kendari}

All other surveyed sites were located in outer Kendari Bay, where impacts of development from Kendari city such as high sedimentation and pollution are less apparent. It is considered that outer Kendari Bay is a suitable location for mariculture, as shown by the relative success of existing activities in the area. It is also verified by the Storet analysis where it scored an overall total of -5 , which is the optimal score of the Index.

\section{Temperature}

Temperature variation within Kendari Bay is very similar to that of other locations in $\mathrm{SE}$ Sulawesi, ranging between $29.5^{\circ} \mathrm{C}-31^{\circ} \mathrm{C}$. Storet analysis shows that Kendari Bay achieved an overall Index score of -1 , which rates the area is suitable for existing mariculture activities.

\section{Water Clarity}

High sedimentation leading to a decline in water clarity is a major concern in Kendari Bay, particularly within the inner area adjacent to the city. The unique geographic formation of the Bay resembles a bottleneck, which has compounded the problem with water clarity due to a lack of flushing effect, especially in the inner part. In the present study of mostly sites in outer Kendari Bay, water clarity (as measured by secchi) ranged between 1.40$8.50 \mathrm{~m}$, with an overall Storet Index score of 1 , which rates the area suitable for existing mariculture activities, especially for seaweed. This storet score is only valid for the outer part of Kendari Bay and not the inner part. Indeed, the government has banned any further farming activities inside the Bay to avoid user conflict with increasing traffic of sea transportation in and out of the Bay.

\section{Depth}

The inshore area of Kendari Bay is characterized by a relatively shallow seabed, with most mariculture activities located in water depth of between 2.1-30.6 m. Some places in Kendari Bay can be as deep as 150 m, and seaweed farming is the only mariculture activity which can be placed in the deeper waters further from the shoreline of the Bay.

\section{pH}

Measured $\mathrm{pH}$ values around Kendari Bay ranged between 6.4-8.3. Storet analysis has given a - 1 score for the area, which rates it as suitable for mariculture activities, especially for seaweed farming.

\section{Dissolved Oxygen}

DO values ranged between $4.7-8.5 \mathrm{mg} / \mathrm{L}$. This condition is regarded as 'good' for any mariculture activities, following the standard of water quality for mariculture published by KLH (2004) where DO is considered optimal if its above $5 \mathrm{mg} / \mathrm{L}$. Storet index value of -1 in Kendari Bay rates DO as 'good' for mariculture.

\section{Salinity}

Range of salinity of the waters within Kendari Bay is between 29.0-33.3 mg/L (ppt), and considered optimal for mariculture activities. Although two relatively big rivers and several small streams discharge into the inner area of Kendari Bay, salinity in the outer area does not fluctuate widely. Storet index value of - 1 for salinity rates outer Kendari Bay as 'good' for mariculture.

\section{Buton Region}

Most mariculture activities around this region are concentrated along Buton Strait and along the coastline of Muna Island that belongs to Buton Regency. The combination of a dispersed coastal population, limited sea transportation traffic and fewer, large-scale industries means this area is still in a relatively natural state compared to the other locations in the Province. However, relatively high sedimentation was observed during the present study, which was caused by active water turbulence driven by the easterly monsoon winds along the Buton coastline that faces Arafura Sea. Suspended sediments are predicted to be highest during this period, as was evident by consistently low water clarity in the area 
closest to the coastline. This might partly explain the reason why seaweed farming, which is more tolerant of variable water quality conditions, has gained more prominence compared to the other mariculture activities.

\section{Temperature}

During the present study, water temperature in this region varied between $26.4^{\circ} \mathrm{C}$ $31.9^{\circ} \mathrm{C}$, with an average of $28.9^{\circ} \mathrm{C}$. The overall Storet Index score for water temperature in the area is -1 , which rates the Buton region as suitable for mariculture. Most areas have stable water temperature, although some locations near the mouths of rivers and coastal straits are likely to be periodically affected by sudden temperature drops caused by large addition of freshwater from monsoonal rains and/ or cooled oceanic seawater from tidal exchange.

\section{Water Clarity}

In the present study, water clarity was poor at some sites, varying between 1.0-11.2 m, with an average of $6.0 \mathrm{~m}$. The overall Storet index value for water clarity was -1 , which is adequate, although further study is required if mariculture is proposed in one particular area. East monsoonal winds caused water turbulence resulting in high turbidity on the east coastline of Buton Island. The western coastline is relatively protected during this season because it is located within Buton Strait. Therefore, most of the existing mariculture locations in this area have relatively good water clarity.

\section{Depth}

In general, most mariculture structures in Buton are built in shallow waters (e.g. for seaweed farming), although areas with deep water are also used if the mariculture construction can be adapted (e.g. floating net cages). The range of depths around existing mariculture activities in this region varies between $1-53.8 \mathrm{~m}$.

\section{pH}

Measured $\mathrm{pH}$ values around existing mariculture locations in Buton are between 7.27.9. The overall Storet Index score for $\mathrm{pH}$ values in the Buton region is 0 , meaning that the water quality rating is 'good' (Class B; has not been polluted) for existing mariculture activities around Buton Island.

\section{Dissolved Oxygen}

Overall, DO variations around Buton Island are within the standard required by any cultured species in this region, ranging between 3.7-9.7 mg/L. It is important to acknowledge that some species need higher DO concentration than other species, and not all parts of Buton Island have waters with adequate DO levels.

\section{Salinity}

Salinity varied between locations in Buton Island during the present study, ranging between $28-31 \mathrm{mg} / \mathrm{L}$, which is acceptable for existing mariculture activities. However, one sampling station at Katilombu village had salinity of $14 \mathrm{mg} / \mathrm{L}$, well below the average for the Island as a whole. This location is surrounded by hills, and elevated run-off from a nearby river flowing into the area has made the salinity level drop to almost half of the standard of other locations. Salinity level is expected to return to background levels once normal river flows resume.

\section{CONCLUSION}

- Three big clusters of existing mariculture activities are located in Kendari, Muna and Buton areas, collectively serving as both a source of mariculture products and a market destination or transit location.

- Most mariculture production in SE Sulawesi is based on traditional practices.

- All surveyed locations of existing mariculture activities in SE Sulawesi show relatively optimal water quality conditions.

- A lack of financial support, knowledge, skill, market information and institutional support has prevented farmers from enhancing their livelihoods through mariculture activities alone.

- Site capacity and suitability analysis of existing or potential areas of mariculture activities and development have largely not been considered by stakeholders involved in managing coastal areas, resulting in crowded and unmanaged development with multiple overlapping economic activities in some areas.

- Piloting of integrated 'value-adding' mariculture industries (e.g. raw material, processed products and 'ready to eat' industries) might help ease some if not all of the 
existing economic problems of the mariculture sector.

- Twice annual time series of water quality measurements representing wet and dry seasons is required to depict the real condition of water quality in SE Sulawesi, for both existing and proposed areas for development.

\section{ACKNOWLEDGMENT}

The present study was supported by Australian Centre for International Agricultural Research (ACIAR) through Assessing Mariculture Market Constraints and Potential in South-East Sulawesi' (SMAR/2007/225).

\section{REFERENCES}

Albasri, H. \& Szuster, B.W. 2010. Mariculture and Marine Spatial Planning: Integrating Local Ecological Knowledge at Kaledupa Island, Indonesia. Island Studies Journal, Canada, 5(2) : 237- 250.

Boyd, C.E. \& Lichtkoppler. 1982. Water Quality Management in Pond Fish Culture. Auburn University. Auburn Alabama, 30 pp.

Centre, L.W. 1977. Environmental Impact Assessment. McGraw-Hill Company. University of Oklahoma, USA.

Cholik, F., Wijono, A., \& Arifudin. 1986. Pengelolaan Kualitas Air Kolam. Direktorat Jenderal Perikanan. Jakarta, 52 pp.

Clark, W.A.V. \& Hosking, P.L. 1986. Statistical Methods for Geographers. John Wiley \& Sons, Inc, $513 \mathrm{pp}$.

DKP Sultra. 2005. Revitalisasi Perikanan Budidaya 2006-2009, p. 275.

GESAMP. 2001. IMO/FAO/UNESCO IOC/WMO/ WHO/IAEA/UN/UNEP Joint group of experts on the scientific aspects of marine environmental Protection), Planning and management for sustainable coastal aquaculture development. Rep.Stud.GESAMP, 68, p. 90.

Gunarso, W. 1985. Tingkah Laku Ikan dalam Hubungannya dengan Alat, Metode, dan
Teknik Penengkapan. Fakultas Perikanan dan Ilmu Kelautan, IPB, Bogor, p. 150.

Kementrian Negara Lingkungan Hidup. 2003. Lampiran I Keputusan Menteri Negara No. 115 Tahun 2003 tentang Penentuan Status Mutu Air dengan Metode Storet. Jakarta: Sekretariat Kementrian Negara Lingkungan Hidup.

Kementrian Negara Lingkungan Hidup. 2008. Lampiran 3 Keputusan Menteri Negara No. 51 Tahun 2004 tentang Baku Mutu Air Laut. Jakarta: Sekretariat Kementrian Negara Lingkungan Hidup.

May, D. \& Coles, T. 2004. Proposed Strategy for The Recovery of The Kaledupan Coastal Fisheries. Wanci: Opwall Trust, p.1-22.

Mayunar, Purba, R., \& Imanto, P.T. 1995. Pemilihan lokasi untuk usaha budi daya ikan laut. Dalam Sudradjat et al. (eds). Prosiding Temu Usaha Pemasyarakatan Teknologi Keramba Jaring Apung bagi Budi daya Laut. Puslitbang Perikanan, Badan Litbang Pertanian, p. 179-189.

Pierre, S., Gaillard, S., Prevot-Dalvise, N., Aubert, J., Rostaing-Capaillon, O., \& Leung-Tack, D. 2007. Grouper aquaculture: Asian success and Mediterranean trials. Aquatic Conservation: Marine and Freshwater Ecosystems.

Purnomo, A. 1992. Pemilihan Lokasi Tambak Udang Berwawasan Lingkungan. Badan Penelitian dan Pengembangan Pertanian, Pusat Penelitian dan Pengembangan Perikanan, p. 40.

Stead, S.M., Burnell, G., \& Goulletquer, P. 2002, Aquaculture and its role in integrated coastal zone management. Aquaculture International, 10: 447-468.

Sunarti. 1992. Pengukuran parameter kualitas air pads longyam dengan tingkat kepadatan 10.000 ikan nila dan 3.000 ikan mas. Laporan Praktek lapangan di Balai Budidaya Air Tawar Sukabumi, p.97.

The GEBCO_08 Grid, Version 20100927. 2008. http://ww.gebco.net. Retrived August, 2009. 